\title{
Sensitivity Analysis of the Penman-Monteith Reference Evapotranspiration to Climatic Variables: Case of Burkina Faso
}

\author{
Papa Malick Ndiaye ${ }^{1 *}$, Ansoumana Bodian1, Lamine Diop², Koffi Djaman³ \\ ${ }^{1}$ Laboratoire Leïdi “Dynamique des Territoires et Développement”, Université Gaston Berger (UGB), Saint Louis, Senegal \\ ${ }^{2}$ UFR S2ATA Sciences Agronomiques, de l’Aquaculture et des Technologies Alimentaires, Université Gaston Berger, Saint-Louis, \\ Senegal \\ ${ }^{3}$ NMSU: Agricultural Science Center at Farmington, Department of Plant and Environmental Sciences, \\ New Mexico State University, Farmington, USA \\ Email: ‘papamalick55@outlook.com, ansoumana.bodian@ugb.edu.sn,iseld2004@yahoo.fr, \\ lamine.diop@ugb.edu.sn,kdjaman@nmsu.edu
}

How to cite this paper: Ndiaye, P.M., Bodian, A., Diop, L. and Djaman, K. (2017) Paper Title. Journal of Water Resource and Protection, 9, 1364-1376. https://doi.org/10.4236/jwarp.2017.912087

Received: September 20, 2017

Accepted: November 13, 2017

Published: November 16, 2017

Copyright @ 2017 by authors and Scientific Research Publishing Inc. This work is licensed under the Creative Commons Attribution International License (CC BY 4.0).

http://creativecommons.org/licenses/by/4.0/

\section{cc) (i) Open Access}

\begin{abstract}
Sensitivity analysis is important in understanding the effect of each climatic input variable on the variation of the evapotranspiration which is a significant element for hydrological modelling, irrigation programs, and water resources management. This study investigates the responses of evapotranspiration to the variation of maximum and minimum temperature, solar radiation, wind speed and maximum and minimum relative humidity. Daily data from 1998 to 2012 of eight stations are used. For each climatic variable, a variation of 5\% up to $\pm 25 \%$ was performed in order to evaluate the sensitivity of the evapotranspiration to the input variables. Results show that evapotranspiration is more sensitive to the variation of solar radiation, maximal temperature and wind speed, respectively.
\end{abstract}

\section{Keywords}

Evapotranspiration, Penman-Monteith, Sensitivity Coefficient, Burkina Faso

\section{Introduction}

Climate change issues have become a major concern in recent years [1] because it may have significant impact on the different components of water cycle: precipitation, runoff and evapotranspiration [1] [2] [3]. Also, it may exacerbate the dry conditions of arid regions by increasing evapotranspiration; thus aggravating the processes of desertification [3]. Among the component of water cycle, the 
evapotranspiration is a key element for agricultural programs, irrigation scheduling, water management and planning [4]-[10]. Several methods have been developed under different climatic conditions to estimate the reference evapotranspiration $\left(\mathrm{ET}_{0}\right)$. Among the various existing methods, Penman-Monteith $\left(\mathrm{ET}_{0_{-} \mathrm{FAO}-\mathrm{PM}}\right)$ was recommended by $\mathrm{FAO}$ as a standard method because its performance under different types of climate [6] [11] [12].

The FAO-Penman-Monteith method integrates climatic variables such temperature, solar radiation, relative humidity and wind speed which may be affected by climate change [13]. Therefore, it is very important to know the sensitivity of $\mathrm{ET}_{\mathrm{O}_{-} \mathrm{FAO} \text {-PM }}$ to the variation of each of these climatic variables. The sensitivity analysis is a way that allows improving understanding not only on the relationships between climatic conditions and $\mathrm{ET}_{0}$ variability but also on the identification of the dominant climatic variables in estimating evapotranspiration [13] [14] [15].

Several studies have investigated the sensitivity analysis of $\mathrm{ET}_{0_{-} \mathrm{FAO} \text {-PM }}$ to the variation of climatic variables [1] [2] [13] [16] [17] [18]. A sensitivity analysis of $\mathrm{ET}_{0}$ to climatic variables in the different climatic regions of USA is conducted by [13]. They used daily time scales and their results showed that $\mathrm{ET}_{0}$ was most sensitive to vapor pressure. In a semi-arid climate in China, [2] used monthly and annual data from fifteen stations over the period 1961-2003 to analyze the sensitivity of $\mathrm{ET}_{0_{-} \text {FAO-PM }}$ to maximum temperature, minimum temperature, mean temperature, wind speed, sunshine duration and relative humidity in the Tao watershed. They showed that the $\mathrm{ET}_{0_{-} \mathrm{FAO} \text {-PM }}$ was more sensitive to variation in relative humidity followed by sunshine duration, wind speed and air temperature. [16] studied the sensitivity of $\mathrm{ET}_{0 \_ \text {FAO-PM }}$ to temperature, solar radiation, relative humidity and wind speed in a semi-arid climate of southern Spain. They concluded that relative humidity, temperature and radiation were the main climatic variables that influence $\mathrm{ET}_{0 \_\mathrm{FAO}-\mathrm{PM}}$. [17] developed a sensitivity coefficient to drive sensitivity analysis of evapotranspiration to temperature, solar radiation and relative humidity at Greece. They concluded that evapotranspiration is more sensitive to the variation of solar radiation and temperature. [1] analyzed the sensitivity of $\mathrm{ET}_{0 \_\mathrm{FAO}-\mathrm{PM}}$ to temperature, and duration sunshine under four climatic conditions: humid, semi-arid hot, semi-arid cold and arid in Iran. They concluded that $\mathrm{ET}_{0_{-} \mathrm{FAO} \text {-PM }}$ is more sensitive to temperature and wind speed in the arid climate, wind speed in the semi-arid climate, and duration of sunshine in wet climate. In West Africa, [18] focused on the sensitivity analysis of $\mathrm{ET}_{0 \mathrm{FAO}-\mathrm{PM}}$ to climatic variables. They found that maximum temperature and solar radiation are the two variables that have more influence on $\mathrm{ET}_{\mathrm{O}_{\mathrm{F}} \mathrm{FO} \text {-PM }}$ at Saint-Louis weather station in the Senegal River Delta. In Burkina Faso, there is no study which focuses on the sensitivity analysis of $\mathrm{ET}_{0_{\mathrm{B}} \mathrm{FAO}-\mathrm{PM}}$ to climatic variables. This research analyzes the sensitivity of $\mathrm{ET}_{0_{-} \mathrm{FAO}-\mathrm{PM}}$ to maximum and minimum temperature, solar radiation, wind speed and minimum and maximum relative humidity in Burkina Faso. 


\section{Material and Method}

\subsection{Study Area}

Burkina Faso is situated in west of Africa between latitude $9^{\circ} 20^{\prime}$ and $15^{\circ} 05^{\prime}$ and longitude $5^{\circ} 20^{\prime} \mathrm{W}$ and longitude $2^{\circ} 05^{\prime} \mathrm{E}$. It covers an area of $274,000 \mathrm{~km}^{2}$ with three climatic zones: Sudan, Sudano-Sahelian and Sahelian zones. The daily mean annual temperature range from $22^{\circ} \mathrm{C}$ to $37^{\circ} \mathrm{C}$ and relative humidity from 30 to over $70 \%$. The highest values $\left(22^{\circ} \mathrm{C}\right.$ to $\left.41^{\circ} \mathrm{C}\right)$ of temperature are observed in March, April and October and the lowest values (15 to 35) in November, December, January and February [19]. From the Sahelian to the Sudanian zone the average annual rainfall increases from 600 to more than $1000 \mathrm{~mm}$ and evapotranspiration is ranging from 500 to more than $1500 \mathrm{~mm}$.

The full daily data of eight weather stations of Burkina Faso over the period 1998-2012 were used. Some characteristics of these stations and their location are presented in Table 1 and Figure 1.

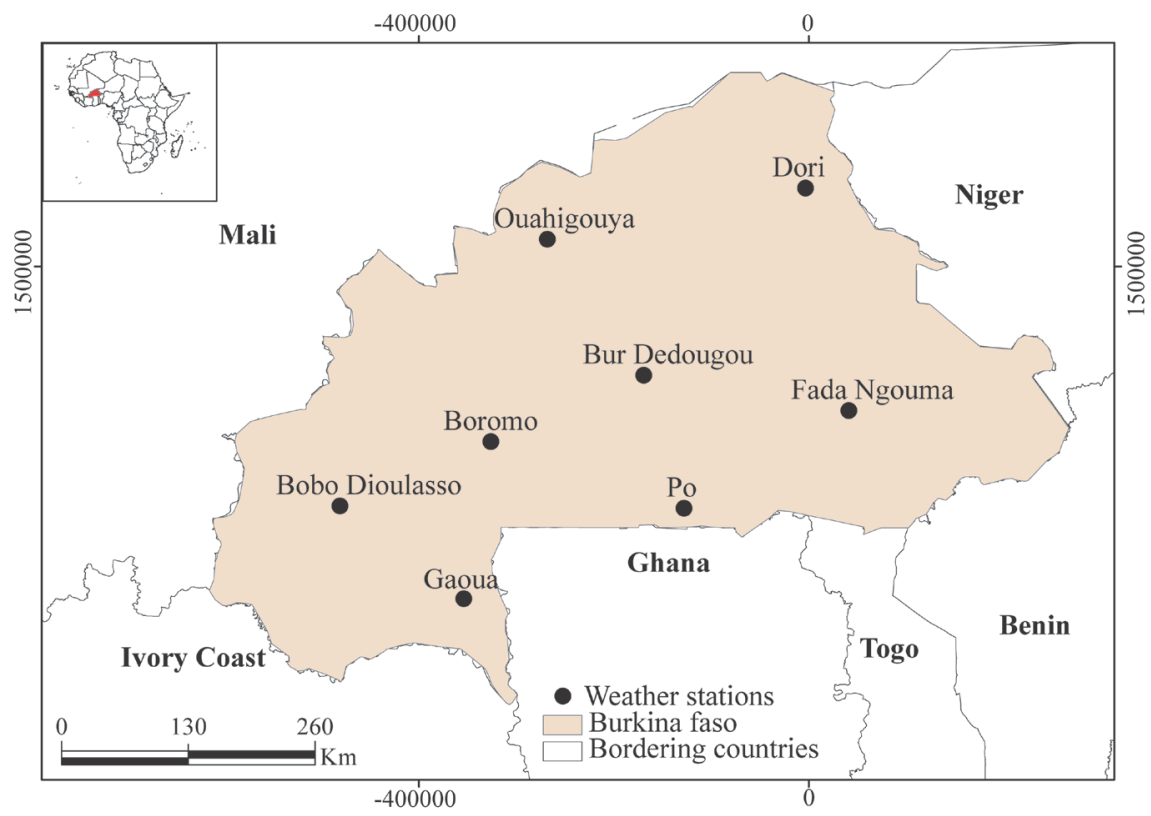

Figure 1. Localization of burkina Faso and the selected weather stations.

Table 1. Characteristics of the weather stations.

\begin{tabular}{ccccc}
\hline Stations & Latitude & Longitude & Altitude $(\mathrm{m})$ & Type of climate \\
\hline Bobo Dioulasso & 11.17 & -4.32 & 445 & Sudanian \\
Gaoua & 10.33 & -3.18 & 339 & Sudanian \\
Boromo & 11.75 & -2.93 & 243 & Sudano-sahelian \\
Bur Dédougou & 12.35 & -1.52 & 305 & Sudano-sahelian \\
Po & 11.15 & -1.15 & 322 & Sudano-sahelian \\
Fada Ngourma & 12.03 & 0.37 & 294 & Sudano-sahelian \\
Dori & 14.03 & -0.03 & 288 & Sahelian \\
Ouahigouya & 13.57 & 0.2 & 315 & Sahelian \\
\hline
\end{tabular}


The data used in this study are minimum and maximum temperature, solar radiation, wind speed and relative humidity. They come from the Africa Rice database (Africa Rice Center). Temperatures are expressed in degrees Celsius $\left({ }^{\circ} \mathrm{C}\right)$, relative humidity in percent (\%), wind speed at a height of $2 \mathrm{~m}$ is expressed in meter by second $\left(\mathrm{m}^{-1} \cdot \mathrm{s}\right)$ and the radiation in mega joule $\left(\mathrm{MJ} \cdot \mathrm{m}^{-2}\right)$. Figure 2 shows the annual evolution of wind speed (a), solar radiation (b), maximal and minimal temperature (c) (d) and maximal and minimal relative humidity (e) (f) at the stations of Bobo Dioulasso, Bur Dedougou and Dori. These stations are used to illustrate the fluctuation of climatic variable during the year. It is to be noticed that the trend remains the same for the other stations.

\subsection{Method}

\subsubsection{Methode of FAO-Penman-Monteith (FAO-PM)}

The FAO-Penman-Monteith (FAO-PM) is standardized method recognized by the Food Agriculture Organization for the estimation of reference evapotranspiration. It requires climatic variables such as temperature, radiation, wind speed and relative humidity [11]. The reference surface is hypothetical grass crop with an assumed crop height of $0.12 \mathrm{~m}$, a fixed surface resistance of $70 \mathrm{~s} \cdot \mathrm{m}^{-1}$ and an albedo of 0.23 [11]. The Penman-Monteith grass reference evapotranspiration equation is:

$$
\mathrm{ET}_{0}=\frac{0.408 \Delta(R n-G)+\gamma \frac{900}{T+273} u 2(e s-e a)}{\Delta+\gamma(1+0.34 u 2)}
$$

where $\mathrm{ET}_{0}=$ reference evapotranspiration ( $\mathrm{mm} /$ day), $R n=$ net radiation at the crop surface $\left(\mathrm{MJ} \cdot \mathrm{m}^{-2} \cdot \mathrm{day}^{-1}\right), G=$ soil heat flux density at the soil surface $\left(\mathrm{MJ} \cdot \mathrm{m}^{-2} \cdot \mathrm{day}^{-1}\right), T=$ mean daily air temperature at $2 \mathrm{~m}$ height $\left({ }^{\circ} \mathrm{C}\right), u 2=$ wind speed at $2 \mathrm{~m}$ height $\left(\mathrm{m} \cdot \mathrm{s}^{-1}\right)$, es = saturation vapor pressure $(\mathrm{kPa})$, ea = actual vapor pressure $(\mathrm{kPa})$, es - ea = saturation vapor pressure deficit $(\mathrm{kPa}), \Delta=$ slope of saturation vapor pressure versus air temperature curve $\left(\mathrm{kPa} \cdot{ }^{\circ} \mathrm{C}^{-1}\right)$ and $\gamma=\mathrm{psy}$ chometric constant $\left(\mathrm{kPa} \cdot{ }^{\circ} \mathrm{C}^{-1}\right)$. All parameters needed for computing $E T_{0}$ was

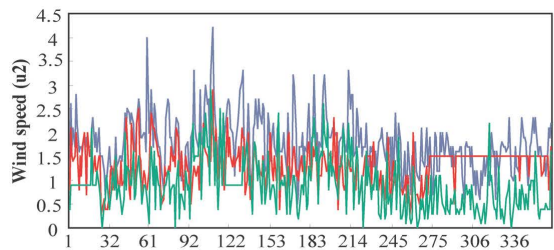

(a)

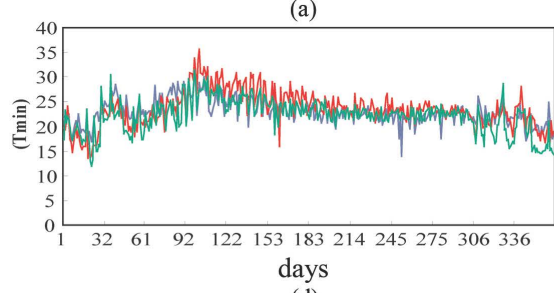

(d)

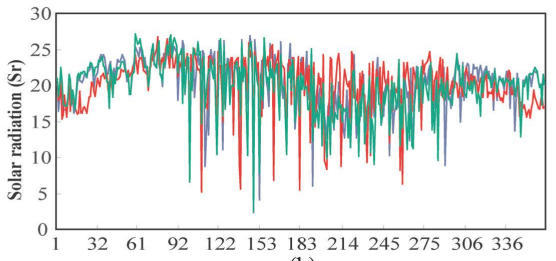

(b)

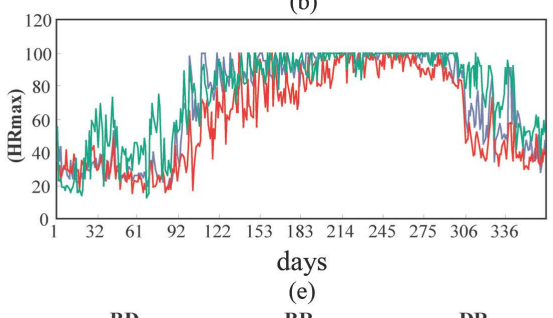

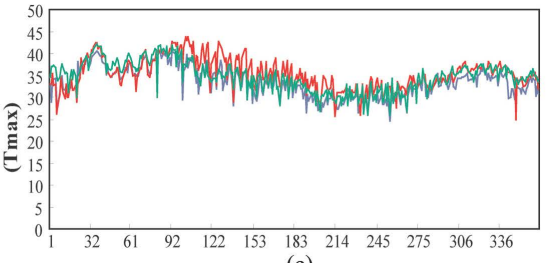

(c)

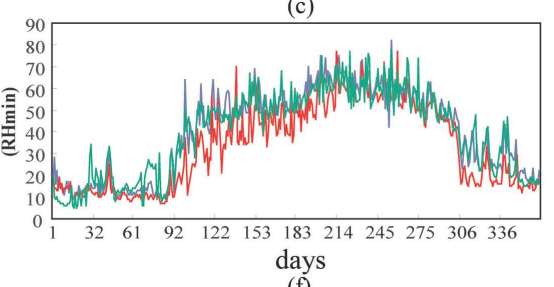

(f)

Figure 2. Variation of climatic variables. 
computed according the procedure developed in FAO-56 by [11].

\subsubsection{Sensitivity Analyses}

The principle of sensitivity analysis consists in varying each climate variable (Tmax, Tmin, Sr, $u 2$, RHmax and RHmin) in order to determine their impact on FAO-PM evapotranspiration. Previous studies reveal that there is no standard procedure for calculating the sensitivity coefficient [13]. But a simple and practical way is to correlate the relative change of dependent variables against the relative change of independent one [2]. In this way, the evapotranspiration calculated by the FAO-PM method is correlated against each climate variable. This comparison allows determining the impact of each climatic variable in $\mathrm{ET}_{0_{\_} \mathrm{FAO}-\mathrm{PM}}$. The coefficient of determination was used as a criterion of evaluation. Furthermore, an increase and decrease of $5 \%, 10 \%, 15 \%, 20 \%$ and $25 \%$ is made on each climatic variable. Each variation of a climatic variable is made individually by keeping constant the others. This increase and decrease allowed determining the variation of the $\mathrm{ET}_{0_{-} \mathrm{FAO} \text {-PM }}$ induced by each climatic variable. The new values of $\mathrm{ET}_{0_{-} \text {FAO-PM }}$ after changing the climatic variable were used to determine the sensitivity coefficient (CS):

$$
C S=\frac{\Delta \mathrm{ET}_{0}}{\Delta C S}
$$

where $C S=$ sensitivity coefficient, $\triangle \mathrm{ET}_{0}=$ change in $\mathrm{ET}_{0_{-} \mathrm{FAO} \text {-PM }}$ entrained by the change of a climate variable and $\triangle C S=$ the unit of change of each variable.

\section{Results and Discussion}

The mean daily monthly evapotranspiration of the eight stations over the period 1998-2012 is presented in Figure 3. The highest values were observed between October and April with a maximum value varying between 5 and $6 \mathrm{~mm} /$ day. This period coincides with the dry season characterized by dry wind and high temperature. On the other hand, during the rainy season, evapotranspiration

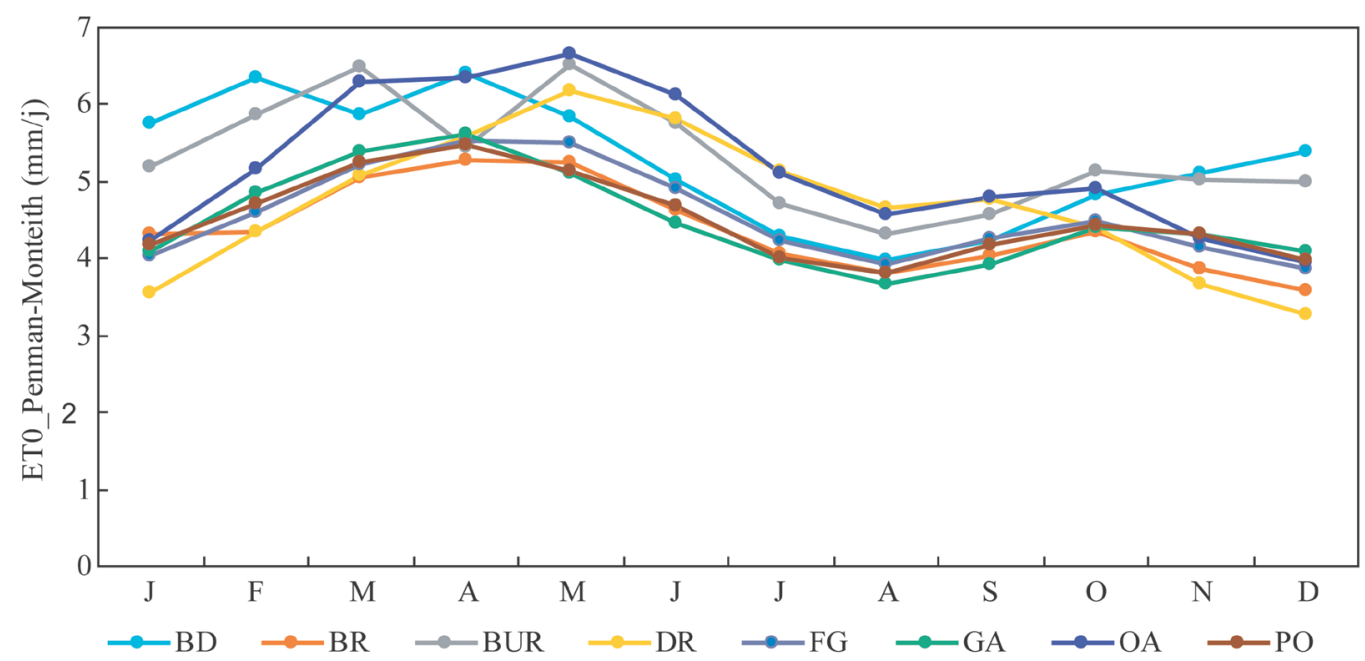

Figure 3. Monthly variation of average daily evapotranspiration. 
tends to fall to a minimum value of $3 \mathrm{~mm} /$ day in August. This decrease in evapotranspiration is explained by the increase in relative humidity during this period.

\subsection{The Sensitivity of Evapotranspiration to the Variation of Climatic Variables}

A simple linear regression was performed between $\mathrm{ET}_{0_{-} \mathrm{FAO} \text {-PM }}$ against solar radiation ( $\mathrm{Sr}$ ), maximum and minimum temperature (Tmax and Tmin), maximum and minimum relative humidity (RHmax and RHmin) and wind speed (u2), separately. Results showed that $\mathrm{ET}_{0_{\mathrm{B} F \mathrm{FO}-\mathrm{PM}}}$ was most sensitive to the variation of solar radiation in Burkina Faso with coefficient of determination of 0.67, 0.64, $0.63,0.56,0.56,0.56,0.53$, and 0.45 at the stations of Fada Ngourma, Gaoua, Po, Dori, Bobo Dioulasso, Boromo, Bur Dedougou and Ouahigouya stations, respectively (Table 2). A positive and negative variation of solar radiation from $5 \%$ to $25 \%$ causes a variation of evapotranspiration from $12.9 \%$ to $64.58 \%(0.129$ to $0.646 \mathrm{~mm} /$ day) at the weather station of Bobo Dioulasso (Figure 4(a)). Similarly, at the station of Fada Ngourma and Dori (Figures 4(e)-(g)) the increase in solar radiation from $5 \%$ to $25 \%$ leads to an increase $\mathrm{ET}_{0 \_ \text {FAO-PM }}$ from $14.74 \%$ to $73.63 \%$ and from $14 \%$ to $70 \%$, respectively. The maximum temperature was the second climatic variable that has more impact to the variation of evapotranspiration. According to the Figure 4, if Tmax increases by 5\%, 10\%, 15\% and 25\% $\mathrm{ET}_{0 \_ \text {FAO-PM }}$ will increase by $11.56 \%, 3.71 \%, 36.49 \%, 49.92 \%$ and $64.05 \%$, respectively. Its decrease in $5 \%$ to $25 \%$ leads also a decrease of evapotranspiration from $10.1 \%$ to $49.1 \%$ at the station of Bobo Dioulasso. At Dori station, increase and decrease of maximum temperature by $5 \%$ to $25 \%$ favor a variation of $\mathrm{ET}_{0}$ from $0.11 \mathrm{~mm}$ to $0.61 \mathrm{~mm}$ and from -0.10 to $-0.47 \mathrm{~mm}(10 \%$ to $60 \%$ and -10 to $-47 \%)$. These results show that evapotranspiration is more sensitive to the increase in maximum temperature than to its decrease.

Wind speed is the third climatic variable that has more influence on evapotranspiration with coefficients of determination ranging from 0.17 to 0.48 . Thus, evapotranspiration increases from $7 \%$ to $36 \%$ when wind speed increases by $5 \%$ to $25 \%$ at the Bobo Dioulasso station. A decrease in wind speed from $5 \%$ to $25 \%$ favors a decrease in $\mathrm{ET}_{0 \_\mathrm{FAO}-\mathrm{PM}}$ from $7.57 \%$ to $38.80 \%$. Contrary to maximum temperature, the decrease in wind speed has more influence on evapotranspiration than its increase. At the stations of Fada Ngourma and Dori, a decrease in wind speed from $5 \%$ to $25 \%$ favors also a decrease in $\mathrm{ET}_{0_{-} \mathrm{FAO}-\mathrm{PM}}$ from 3.87 to 19.60 and from $4.6 \% 7$ to $23.61 \%$. The minimum temperature has values closed to that of the wind speed with coefficients of determination ranging from $14 \%$ to $49 \%$ depending on the stations (Table 2). However, Figure 4 shows that the influence of wind speed on $\mathrm{ET}_{0_{-} \mathrm{FAO} \text {-PM }}$ is minimal compared to that of radiation, maximum temperature and wind speed. Indeed, the increase and decrease of Tmin from $5 \%$ to $25 \%$ also lead to an increase and decrease in $\mathrm{ET}_{0_{-} \mathrm{FAO}-\mathrm{PM}}$ from 3 to $18 \%$ and from $2 \%$ to $11 \%$ at Bobo Dioulasso station. 
Table 2. Simple linear regression of $\mathrm{ET}_{0 \_\mathrm{FAO}-\mathrm{PM}}$ against each climate variable.

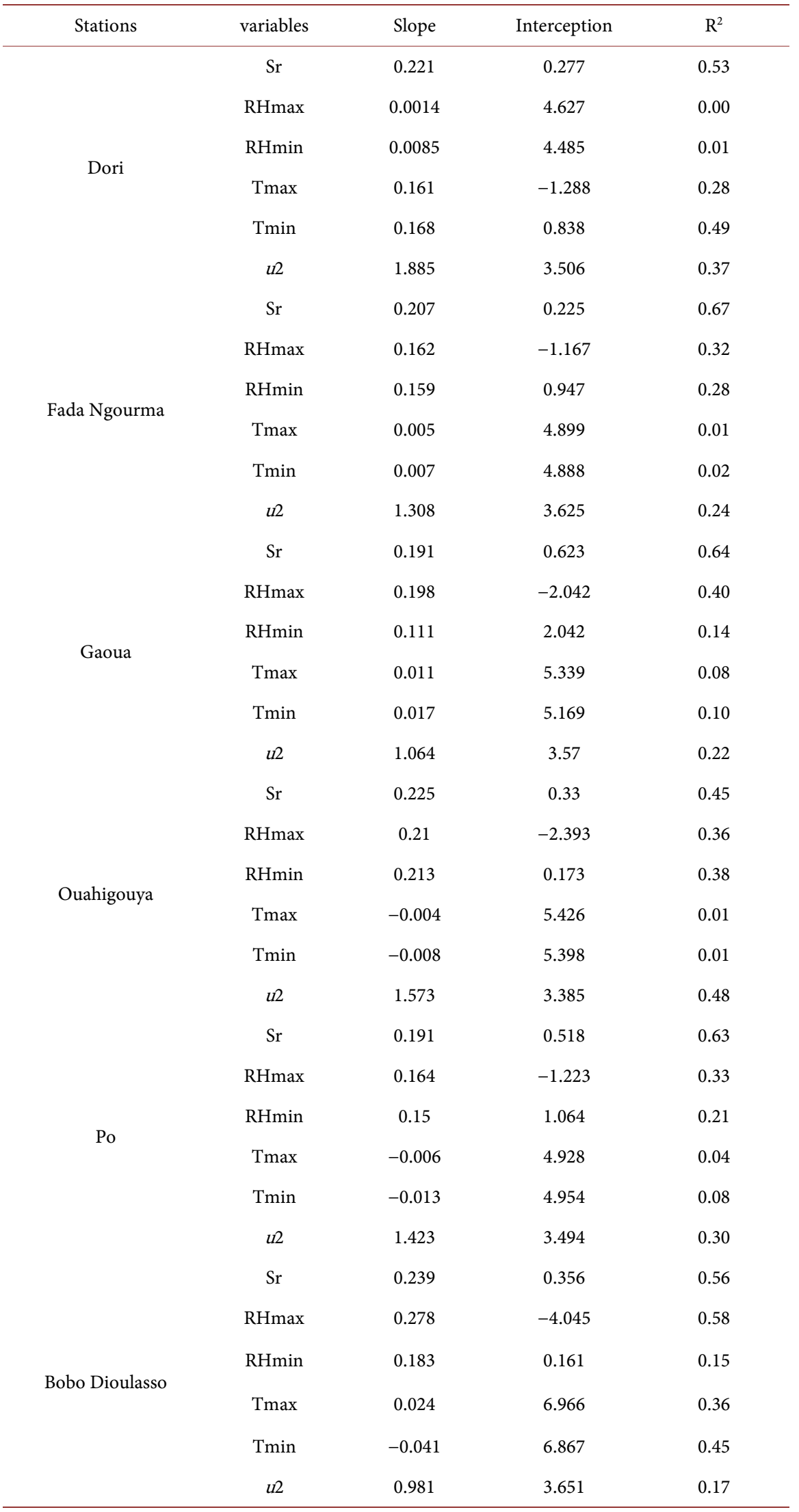




\begin{tabular}{|c|c|c|c|c|}
\hline Continued & & & & \\
\hline \multirow{6}{*}{ Boromo } & $\mathrm{Sr}$ & 0.179 & 0.611 & 0.56 \\
\hline & RHmax & 0.153 & -1.129 & 0.32 \\
\hline & RHmin & 0.144 & 1.066 & 0.29 \\
\hline & $\operatorname{Tmax}$ & -0.003 & 4.56 & 0.01 \\
\hline & Tmin & -0.007 & 4.585 & 0.02 \\
\hline & $u 2$ & 1.342 & 3.584 & 0.23 \\
\hline \multirow{6}{*}{ Bur Dedougou } & $\mathrm{Sr}$ & 0.228 & 0.615 & 0.56 \\
\hline & RHmax & 0.229 & -2.672 & 0.48 \\
\hline & RHmin & 0.141 & 2.22 & 0.19 \\
\hline & $\operatorname{Tmax}$ & -0.018 & 6.57 & 0.20 \\
\hline & Tmin & -0.029 & 6.363 & 0.22 \\
\hline & $u 2$ & 1.332 & 3.497 & 0.27 \\
\hline
\end{tabular}

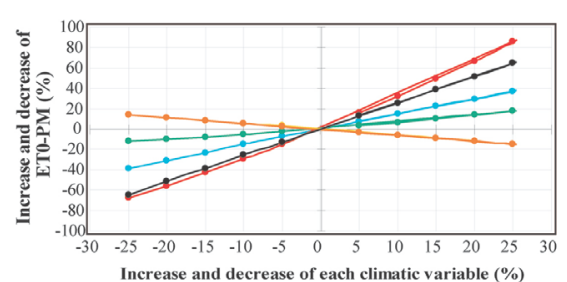

(a)

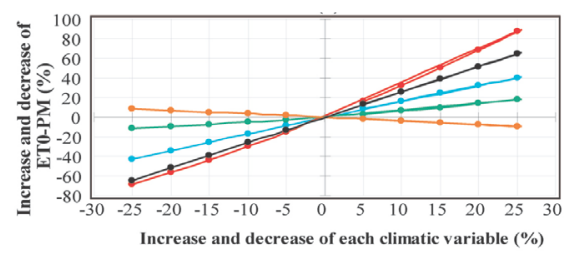

(d)

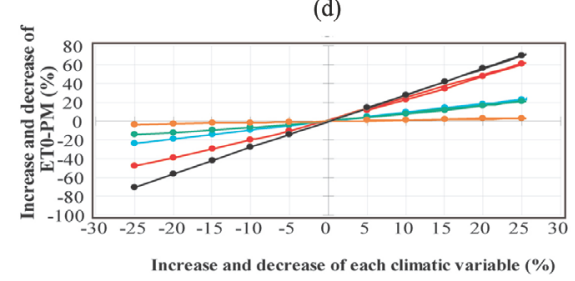

(g)

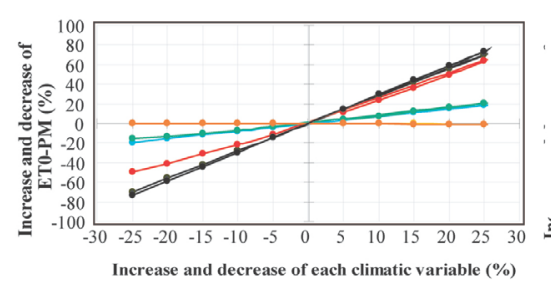

(b)

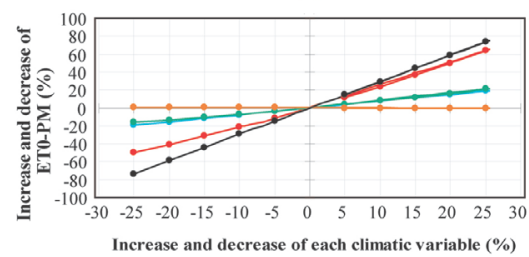

(e)

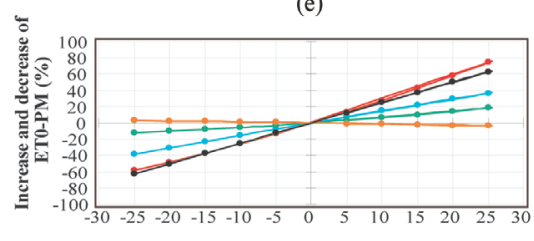

Increase and decrease of each climatic variable (\%)

(h)

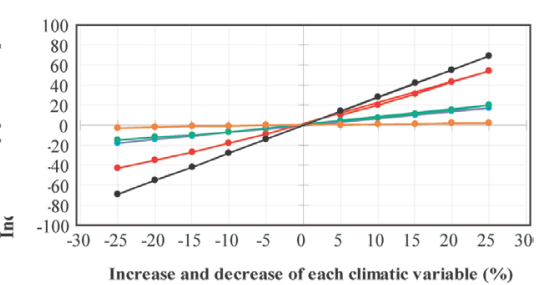

(c)

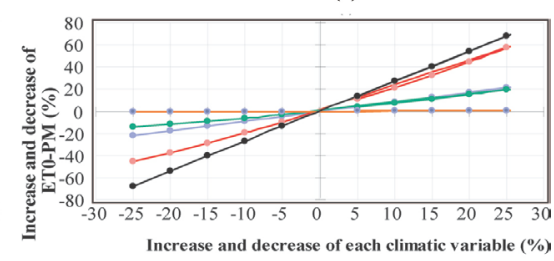

(f)

Figure 4. Change of $\mathrm{ET}_{0 \text {-FAO-PM }}$ function of the change of climatic variables.

However, relative humidity has less influence on $\mathrm{ET}_{0_{-} \mathrm{FAO}-\mathrm{PM}}$ because of the low coefficient of determination which varies only between $0 \%$ and $8 \%$ for maximum relative humidity and $1 \%$ and $10 \%$ for minimum relative humidity (Table 2). The relative humidity follows an opposite trend compared to the other variables because its increase of $5 \%$ to $25 \%$ causes a decrease of $\mathrm{ET}_{0_{-} \mathrm{FAO}-\mathrm{PM}}$ from 0.029 to $0.147 \mathrm{~mm}(-2.89$ to $-14.68 \%)$ at the Bobo Dioulasso station. This observation allows noting that the increase in relative humidity causes a decrease in the rate of evapotranspiration and vice versa. In arid and semi-arid climate 
where temperature is high the rate of evapotranspiration may be important.

The results of this study are in agreement with those of [17] [18] and [20]. In the Delta of the Senegal River, [18] showed that evapotranspiration was more sensitive to maximum temperature and wind speed. By studying the sensitivity of evapotranspiration computed by five methods (Fao 56 Penman-Monteith, Fao 24 Penman, Fao 24 Blaney-Criddle, Fao 24 Makking and Hargreaves), [17] concluded that solar radiation and temperature have more influence on evapotranspiration than wind speed and relative humidity. And [20] analyzed the sensitivity of maximum temperature, minimum temperature, wind speed and sunshine in Spain. Their results showed that $\mathrm{ET}_{\mathrm{O}_{\mathrm{F} \mathrm{FAO}-\mathrm{PM}}}$ was less sensitive to minimum temperature even less at sunshine. But it is more sensitive to variation in maximum temperature and wind speed. However, contrary to our results where relative humidity is the variable that has less influence on $\mathrm{ET}_{0_{-} \mathrm{FAO} \text {-PM}}$, [21] noted that evapotranspiration is more sensitive to changes in relative humidity, followed by radiation, temperature and wind speed in coastal and mountain regions of West Korea.

\subsection{The Monthly Change in the Sensitivity of $\mathrm{ET}_{0_{-} \text {FAO-PM }}$ to Climatic Variables}

The sensitivity coefficient for each climate variable was calculated to highlight the impact of each variable on $\mathrm{ET}_{0_{-} \mathrm{FAO} \text {-PM }}$ and to show its variation as a function of the months. Figure 5 shows the monthly variations and Table 2 gives the mean values of the sensitivity coefficients for each climatic variable over the study period as a function of climatic zones.

The results show that at Bobo Dioulasso station (Figure 5(a)), maximum temperature has more influence on the change in evapotranspiration, from
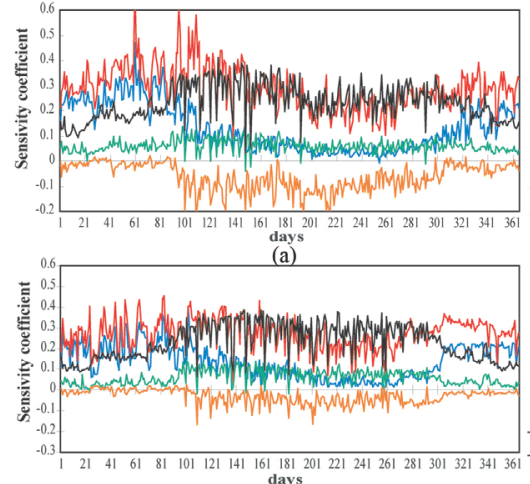

(d)

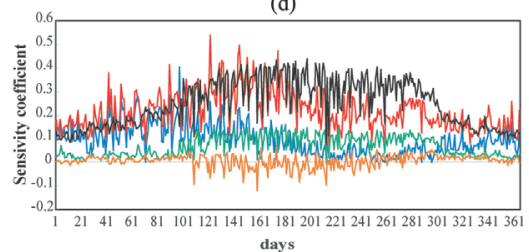

(g)

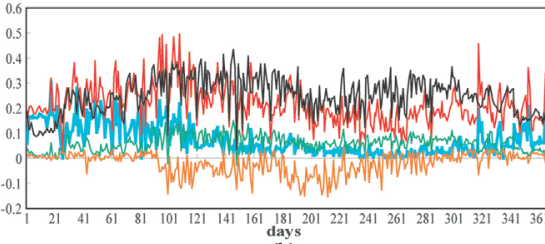

(b)

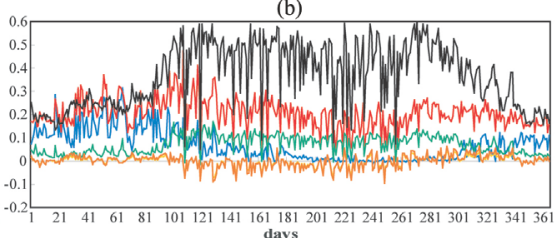

(e)

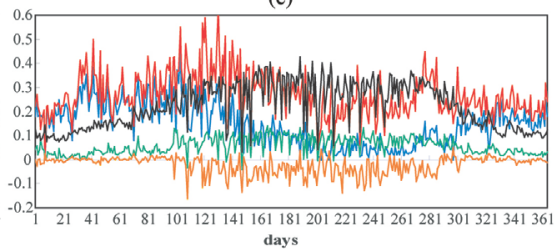

(h)

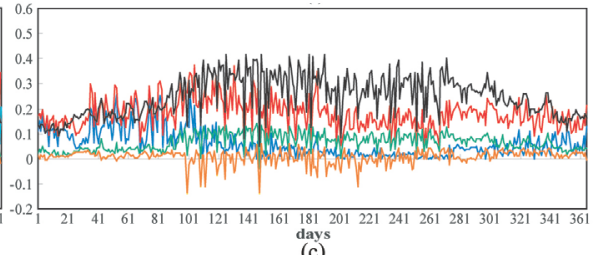

(c)

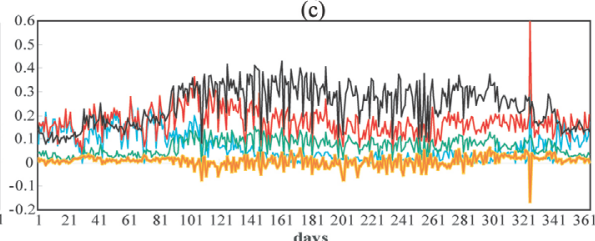

(f)

Figure 5. Variation of daily average sensitivity coefficient at the different stations. 
Table 3. Sensitivity coefficient of the climatic variables.

\begin{tabular}{|c|c|c|c|c|c|c|c|}
\hline Climatic zones & Stations & $\mathrm{Sr}$ & Tmax & $u 2$ & Tmin & RHmax & RHmin \\
\hline \multirow{2}{*}{ Soudanian } & Bobo Dioulasso & 0.23 & 0.29 & 0.13 & 0.06 & -0.06 & -0.06 \\
\hline & Gaoua & 0.25 & 0.21 & 0.07 & 0.06 & -0.02 & -0.02 \\
\hline \multirow{4}{*}{ Soudano-sahelian } & Boromo & 0.25 & 0.18 & 0.06 & 0.07 & 0.01 & 0.01 \\
\hline & Bur Dedougou & 0.23 & 0.27 & 0.13 & 0.06 & -0.03 & -0.03 \\
\hline & Fada Ngourma & 0.37 & 0.20 & 0.07 & 0.07 & 0.00 & 0.00 \\
\hline & Po & 0.24 & 0.17 & 0.07 & 0.07 & 0.01 & 0.01 \\
\hline \multirow{2}{*}{ Sahelian } & Dori & 0.25 & 0.22 & 0.09 & 0.07 & 0.01 & 0.01 \\
\hline & Ouahigouya & 0.22 & 0.27 & 0.15 & 0.06 & -0.02 & -0.02 \\
\hline
\end{tabular}

December to May, followed by wind speed and solar radiation. From May to November the variation of the coefficients of sensitivity of maximum temperature and solar radiation is almost identical. The maximum values of Tmax are observed in March and April and go up to 0.6. Tmax, Sr, and $u 2$ are the three variables that have more impact on $\mathrm{ET}_{0_{-} \text {FAO-PM }}$ at Bobo Dioulasso station with average values of $0.29,0.23$ and 0.13 , respectively (Table 3). As for Gaoua station (Figure 5(d)), the sensitivity coefficients for all variables fluctuate between -0.1 and 0.25 . Evapotranspiration is more sensitive to the variation in radiation and maximum temperature which have 0.25 and 0.21 , respectively. From mid-December to April Tmax and $u 2$ have more influence on $\mathrm{ET}_{0_{-} \mathrm{FAO}-\mathrm{PM}}$ than $\mathrm{Sr}$. Relative humidity (max and min) has very low sensitivity coefficients with mean values of -0.06 and -0.02 for the two respective stations.

The average sensitivity coefficients for Sr, Tmax, $u 2$, Tmin and RH ( $\max$ and $\mathrm{min}$ ) are $0.25,0.18,0.07,0.06$ and 0.01 respectively at Boromo station (Figure 5(b)). The effect of wind speed, minimum temperature and relative humidity on $\mathrm{ET}_{0 \_ \text {FAO-PM }}$ is insignificant from March to December. The results of the station of Bur Dedougou (Figure 5(c)) are however a little different from those of the station of Boromo. At this station, evapotranspiration is more influenced, from November to mid-May, by the maximum temperature followed by the wind speed and the radiation arrives in third position. On the other hand, for the rest of the year (mid-May-October), the sensitivity coefficient of $\mathrm{Sr}$ and Tmax are almost identical with a slight domination of solar radiation. Nevertheless, the maximum temperature which has a sensitivity coefficient of 0.27 has more influence on the $\mathrm{ET}_{0 \_ \text {FAO-PM }}$ than $\mathrm{Sr}$ and $u 2$ which have 0.23 and 0.13 . However, the coefficients sensitivity of Tmin and RH are weak (0.06 and -0.03). Overall, the wind effect is more noticeable between January and April, the dry season in Burkina Faso with the dominance of the Harmattan (hot and dry wind). The values of $u 2$ also drop between April and September (rainy season) according to the change in relative humidity.

For the Dori station (Figure 5(g)), Tmax and Sr are always the climatic variables that have more influence on the $\mathrm{ET}_{0_{-} \mathrm{FAO}-\mathrm{PM}}$ with 0.25 and 0.22 . The impact of wind speed at this station is minimal due to its low sensitivity coefficient 
(0.09). It approximates the sensitivity coefficient of Tmin which has a minimum value of 0.07 . The sensitivity of wind speed is more significant from October to May, but from June to August the effect of Tmin is more significant. However, the results of Ouahigouya station (Figure 5(h)) are not very different to those of Dori. From mid-November to April temperature wind speed have more influence FAO-PM evapotranspiration and from May to mid-November ET $_{0_{-} \text {FAO-PM }}$ is most sensitive to maximum temperature and solar radiation. The coefficients of Tmax, Sr and $u 2$ are $0.27,0.22$ and 0.15 respectively. The maximum temperature is more significant in March and April with sensitivity coefficients up to 0.6 and decreases in June, July, August and September, which also correspond to the rainy season. The influence of the minimum temperature and the relative humidity is always negative with sensitivity coefficients of 0.06 and -0.02 .

Overall, for all stations, the sensitivity of evapotranspiration to climatic variables is more significant during the dry season from October to May. The importance of measuring climatic variables over a specific period has been noted by some authors around the world. Thus, [16] in their study of sensitivity analyses in southern Spain (Andalusia), noted that it is important in semi-arid regions to measure temperature or solar radiation during the summer than during the winter months for a better estimate of evapotranspiration. [22] analyzed the sensitivity of $\mathrm{ET}_{0_{-} \text {FAO-PM }}$ to mean air temperature, vapor pressure deficit, wind speed and solar radiation at Karma in Iran in a semi-arid climate. These authors abound in the same sense as [16] because their results show that $\mathrm{ET}_{0 \_\mathrm{FAO}-\mathrm{PM}}$ is more sensitive to the vapor pressure deficit every month, to wind speed from November to March and to solar radiation during the summer. [23] also noted that $\mathrm{ET}_{0 \_\mathrm{FAO} \text { PM }}$ is more sensitive to the mean air temperature for many of the eight stations they used in Iran and this sensitivity is higher during the summer than during winter.

\section{Conclusions}

The aim of this study was to analyze the sensitivity of $\mathrm{ET}_{0 \_ \text {FAO-PM }}$ to maximum and minimum temperature, solar radiation, wind speed and relative maximum and minimum humidity in Burkina Faso. The $\mathrm{ET}_{\text {0_FAO-PM }}$ was first calculated for each month and then each climate variable was correlated with the values of $\mathrm{ET}_{0 \_ \text {FAO-PM }}$ obtained in order to determine their influence on it. A positive and negative variation of $5 \%$ to $25 \%$ (step $5 \%$ ) was done and the new set of data allowed determining the sensitivity coefficient.

Results showed that the minimum and maximum values of $E T_{0}$ fluctuate around 3 and $6 \mathrm{~mm} /$ day. The highest values were observed in March and April and the lowest in August. The sensitivity analysis showed overall that the change in $\mathrm{ET}_{0 \_\mathrm{FAO}-\mathrm{PM}}$ is much more sensitive to changes in solar radiation, maximum temperature and wind speed. The effects of minimum temperature and relative humidity are not significant. Relative humidity was the variable that has less influence on the change in evapotranspiration for all climatic zones. The sensitivi- 
ty coefficients vary from 0.22 to 0.37 for solar radiation, from 0.17 to 0.29 for the maximum temperature and from 0.06 to 0.15 for the wind speed according to climatic zones of Burkina.

Overall, the results of this study show that for a better estimation of $E T_{0}$, attention is required in the measurement of radiation and maximum temperature and the wind speed must also be taken seriously because it has a considerable impact on evapotranspiration.

\section{Acknowledgements}

We would like to thank all the reviewers of the Journal of Water Resource and Protection (JWARD) who contributed significantly to the evaluation of this manuscript. We appreciate their constructive suggestions. The principal author thanks the heads of the regional center (Africa Rice) who accepted to host him as a trainee as part of his Master's thesis.

\section{References}

[1] Tabari, H. and Talaee, P.H. (2014) Sensitivity of Evapotranspiration to Climate Change in Different Climates. Global and Planetary Change, 115, 16-23. https://doi.org/10.1016/j.gloplacha.2014.01.006

[2] Liang, L., Li, L., Zhang, L., Li, J. and Li, B. (2008) Sensitivity of Penman-Monteith Reference Crop Evapotranspiration in Tao's River Basin of Northeastern China. Chinese Geographical Science, 18, 340-347.

[3] Attorad, A., Kheirkhali, F., Sigaroodi, S.H.K.L. and Sadeghi, S.M.M. (2015) Sensitivity of Reference Evapotranspiration to Global Warming in the Caspien Region, North of Iran. Journal of Agricultural Science and Technology, 17, 869-883.

[4] Xu, C.Y. and Singh V.P. (1998) Dependence of Evaporation on Meteorological Variables at Different Time Scales and Intercomparison of Estimation Methods. $\mathrm{Hy}$ drological Process, 12, 429-442. https://doi.org/10.1002/(SICI)1099-1085(19980315)12:3<429::AID-HYP581>3.0.CO ;2-A

[5] Adeboye, O.B., Osunbitan, J.A., Adekalu, K.O. and Okunade, D.A. (2009) Evaluation of FAO-56 Penman-Monteith and Temperature Based Models in Estimating Reference Evapotranspiration. Agricultural Engineering International, the CIGR Ejournal Manuscript, 1291, 1-25.

[6] Bakhtiari, B., Ghlirman, N., Liaghat, A.M. and Hoogenboom, G. (2011) Evaluation of Reference Evapotranspiration Models for a Semi-Arid Environment Using Lysimeter Measurements. Journal of Agricultural Science and Technology, 13, 223-237.

[7] Jia, X., Scherer, T.H., Lin, D., Zhang, X. and Refal, I. (2013) Comparison of Reference Evapotranspiration Calculations for Southeastern North Dakota. Irrigation and Drainage Systems Engineering, 3, 1-9.

[8] Heydari, M.M., Aghamajidi, R., Beygipoorgh, G. and Heydari, M. (2014) Comparison and Evaluation of 38 Equations for Estimating Reference Evapotranspiration in an Arid Region. Fresenius Environmental Bulletin (FEB), 8, 1985-1996.

[9] Naorem, N. and Thak, D. (2014) Estimation of Potential Evapotranspiration Using Empirical Models for Imphal. International Journal of Innovative and Exploring Engineering (IJITEE), 7, 119-123. 
[10] Djaman, K., Balde, A.B., Sow, A., Muller, B., Irmak, S., Ndiaye, M.K., Manneh, B., Moukoumbi, Y.D., Fatakuchi, K. and Saito, K. (2015) Evaluation of Sixteen Reference Evapotranspiration Methods under Sahelian Conditions in the Senegal River Valley. Journal of Hydrology: Regional Studies, 3, 139-159.

[11] Allen, R.G., Pereira, L.S., Raes, D. and Smith, M. (1998) Crop Evapotranspiration. Guidelines for Computing Crop Requirements. FAO-Irrigation and Drainage Paper 56, Rome, 333. http://academic.uprm.edu/abe/backup2/tomas/fao\%2056.pdf

[12] Marti, P., Zargo, M., Vanderlinden, K. and Girona, J. (2015) Parametric Expressions for the Adjusted Hargreaves Coefficient in Eastern Spain. Journal of Hydrology, 529, 1713-1724. https://doi.org/10.1016/j.jhydrol.2015.07.054

[13] Irmak, S., Payero, J.O., Martin, D.L., Irmak, A. and Howell, T.A. (2006) Sensitivity Analyses and Sensitivity Coefficients of Standardized Daily ASCE-Penman-Monteith Equation. Journal of Irrigation and Drainage, Engineering, 6, 564-578. https://doi.org/10.1061/(ASCE)0733-9437(2006)132:6(564)

[14] Gong, L., Xu, C.H., Chen, D., Holldan, S. and Chen, Y.D. (2006) Sensitivity of the Penman-Monteith Reference Evapotranspiration to Key Climatic Variables in the Changzing (Yantze River) Basin. Journal of Hydrology, 329, 620-629. https://doi.org/10.1016/j.jhydrol.2006.03.027

[15] Mosaedi, A., Ghabaei, M., Sadeghi, S.-H., Mooshakhian, Y. and Bannayon, M. (2015) Sensitivity Analysis of Monthly Reference Crop Evapotranspiration Trends in Iran: A Qualitative Approach. Theoretical and Applied Climatology, 1-17.

[16] Estevez, J., Gavilan, P. and Berenena, J. (2009) Sensitivity Analysis of a Penman-Monteith Type Equation to Estimate Reference Evapotranspiration in Southern Spain. Hydrological Processes, 23, 3342-3353.

[17] Ambas, V.Th. and Batas, E. (2012) Sensitivity Analysis of Different Evapotranspiration Methods Using a New Sensitivity Coefficient. Global Nest Journal, 3, 335-343.

[18] Djaman, K., Tabari, H., Baldé, A.B., Diop, L., Futakuchi, K. and Irmak, S. (2016) Analyses, Calibration and Validation of Evapotranspiration Models to Predict Grass-Reference Evapotranspiration in the Senegal River Delta. Journal of Hydrology: Regional Studies, 8, 82-92. https://doi.org/10.1016/j.ejrh.2016.06.003

[19] Ouédrago, M. (2012) Impact des changements climatiques sur les revenus agricoles au Burkina Faso. [Impact of Climate Change on Agricultural Incomes in Burkina Faso.] Journal of Agriculture and Environment for International Development (JAEID), 1, 3-21.

[20] Vicente-Serrano, S.M., Azorin-Molina, C., Sanchez-Lorenzo, A., Revuelto, J., Maran-Tegeda, E., Lopez-Marena, J.I. and Espezo, F. (2014) Sensitivity of Reference Evapotranspiration to Change in Meteorological Parameters in Spain (1961-2011). Water Resources Research, 50, 8458-8480. https://doi.org/10.1002/2014WR015427

[21] Aydin, M., Yung, Y.-S., Young, J.E., Kim, S.J. and Kim, K.-D. (2015) Sensitivity of Soil Evaporation and Reference Evapotranspiration to Climatic Variables in South Korea. Turkish Journal of Agriculture \& Forestry, 39, 652-662.

[22] Bakhtiari, B. and Liaghat, A.M. (2011) Seasonal Sensitivity Analysis for Climatic Variables of ASCE-Penman-Monteith Model in a Semi-Arid Climate. Journal of Agriculture and Technology, 17, 1135-1145.

[23] Sharifi, A. and Dinpashah, Y. (2014) Sensitivity Analysis of the Penman-Monteith Reference Crop Evapotranspiration to Climates Variables in Iran. Water Resource Manage, 28, 5461-5476. https://doi.org/10.1007/s11269-014-0813-x 